\title{
Breeding ecology and success of a reintroduced population of the endangered Crested Ibis Nipponia nippon
}

\author{
XIAOPING YU, XIA LI and ZHIPING HUO
}

\begin{abstract}
Summary
Reintroduction projects usually attempt to re-establish a self-sustaining population of endangered species within their historical ranges through the release of captive-bred individuals into the wild. We studied the breeding biology and nesting success of a reintroduced population of Crested Ibis Nipponia nippon in Ningshan County on the south slope of the Qinling Mountains of Shaannxi Province, China. From May 2007 to October 2011, 56 captive-bred individuals, composed of 26 females and 30 males, were released into the area and monitored using radio-telemetry. The average age of individuals at release was $5.2 \pm 2.5$ years for females and $6.4 \pm 2.9$ years for males. Mean clutch size was $3.14 \pm 1.06$ (range 1-5). Mean number of fledglings per active nest was $1.57 \pm 1.03$ and mean number of fledglings per successful nest was $2.00 \pm 0.87$. Most of the fledglings survived to complete their post-fledging dispersal. Mean annual survival rate was $0.552 \pm 0.064$ for all released birds, $0.815 \pm 0.054$ for breeders, and $0.515 \pm 0.058$ for first year fledglings. The average number of young produced/year/pair was $1.57 \pm 1.03$ and the growth rate $(\lambda)$ of the reintroduced population was 1.2193 . We confirmed that starvation and predation by King Rat Snake Elaphe carinata were the main causes of death of released individuals, nestlings and fledglings. This is the first attempt to reintroduce captive-bred Crested Ibis to former natural habitat. The ability of captive-bred ibis to survive and breed successfully bodes well for future releases of this and other endangered species.
\end{abstract}

\section{Introduction}

Of the 9,672 extant species of bird, 1,111 are threatened by extinction, and 97 out of 108 bird extinctions since 1600 have been on islands (Collar et al. 1994). Extinction seems to be inevitable for most Critically Endangered species, but sometimes the efforts of committed individuals are able to bring some from the brink of extinction. By the early 1950s, the population of the Hawaiian Goose Branta sandvicensis had fallen to about 30 individuals, but a reintroduction programme brought the bird's numbers back to a sustainable level (Black and Banko 1994). The decline of the Mauritius Kestrel Falco punctatus was even more desperate, only four individuals remaining by the mid-1970s. Again, captive breeding programmes were instrumental in saving the bird, which recovered to a population of several hundred (Cade and Jones 1993, Jones et al. 1995, Cade and Burnham 2003). Reintroductions of endangered species to their former ranges have helped restore declining bird populations worldwide (Rudolph et al. 1992, Armstrong et al. 1999). With recent increases in the numbers of species reintroduction projects, a recognizable field of reintroduction biology has emerged (Seddon et al. 2007), which is part of a conservation strategy to save the Crested Ibis Nipponia nippon (Yu et al. 2009). 
The ultimate success of reintroductions is critically dependent on the ability of the released animals to establish self-sustaining populations in the release habitat, involving fidelity to release area, long-term survival and breeding success (Armstrong et al. 1999). The number of birds released in a reintroduction programme also strongly correlates with release success (Green 1997, Wolf et al. 1998). Habitat quality such as food richness, predator abundance and human disturbance may be even more important determinants of reintroduction success, particularly for longterm persistence (Armstrong and McLean 1996, Wolf et al. 1998). The long-term goal of any reintroduction projects should be the creation of viable populations that replicate as closely as possible the behaviour and ecology of the original wild population (Meretsky et al. 2001).

Captive populations can exhibit more behavioural variation than their wild counterparts as a result of relaxed selective pressures in the captive environment. These variations can translate into decreased survival upon reintroduction to released habitats (Mcphee and Silverman 2004). Failure of released captive-bred animals to breed successfully in the wild may result from poor behavioural adjustment, lack of suitable breeding partners, genetic abnormalities, or poor ecological conditions. Demographic data such as breeding success are essential in determining the mechanisms responsible for reintroduction success or failure (Armstrong et al. 2002). Environmental and demographic stochasticity are also likely to have a long-term effect on very small reintroduced populations (Simberloff 1988, May 1991). Moreover, all biological factors able to play a role in population viability do so by acting on survival and fecundity rates, whatever their genetic, behavioural or environmental origin. Therefore, field study on demography of a species is crucial to assessing the possible effects of all factors affecting reintroduction success (Sarrazin and Barbault 1996). In that way, comparative studies of breeding ecology can provide useful information for the management of a released population.

Crested Ibis was once one of eastern Asia's most widespread birds. However, deforestation and destruction of its habitat, and illegal hunting led to successive extirpations of Russian, Korean, and Japanese populations in the 20th century (Yamashina 1967, Archibald et al. 1980). The Crested Ibis population, which had been presumed extinct since the 1960s, was rediscovered in $198 \mathrm{I}$ in a small mountain village (Yao Jiagou) in Yangxian County of Shaanxi Province. At that time, the world population of Crested Ibis stood at only seven, including two pairs and three chicks (Liu 1981). During the past 30 years, a great deal of conservation effort both in situ and ex situ, has been successfully undertaken. The protection measures taken include local legislation, effective management of nesting and foraging habitats, periodic surveys and monitoring, and public education (Shi and Cao 2001, Ding 2004). The wild population has increased from seven to approximately 800 . From 1981 to 1987 , six wild nestlings were captured and a first attempt at captive breeding of the Crested Ibis was conducted in Beijing Zoo (Li 1991). To date, more than 1,000 captive-bred individuals reside in twelve conservation breeding centres or zoos located in China, Japan and Korea. The successful breeding programme for this species has made it possible to reintroduce this rare bird to its historical range.

A reintroduction programme was conducted at Zhaigou village, Ningshan County in Shaannxi Province China in 2007 in order to establish a new population within the former range. The ultimate goal is to increase numbers in the wild to a healthy population size at which the species may be eligible for downlisting. The programme achieved one of its first goals when two pairs successfully fledged three young in the first breeding season (Yu et al. 2009).

To establish a new population, it is essential for the released birds to survive during the establishment phase, to settle in to the reintroduction area, to pair and nest successfully, and to recruit sufficient young individuals to balance mortality. In the present study, the released birds were monitored using radio-telemetry and colour-banding to examine the reproductive potential of captive-reared ibis in this habitat. Specifically, we sought to (I) determine whether captive-reared birds were capable of pairing and breeding in the wild; (2) document behaviour and breeding success of the reintroduced individuals; (3) compare reproductive parameters between the released population and the wild population in Yangxian County studied by Yu et al. (2006); (4) calculate survival rates for released birds, breeders and first year fledglings; (5) compare growth rates for 
the reintroduced and natural populations (Lu et al. 2000, Ding 2004 ); and (6) determine factors limiting population growth in the newly established population. The results have implications for both Chinese Crested Ibis recovery and other reintroduction programmes.

\section{Methods}

\section{Study area}

We conducted a four year study (2008-2011) of the breeding ecology of released Crested Ibis at Ningshan County $\left(33^{\circ} \mathrm{O} 7^{\prime}-33^{\circ} 50^{\prime} \mathrm{N}, 108^{\circ} \mathrm{O} 2^{\prime}-108^{\circ} 5^{\prime} \mathrm{E}\right)$ on the south slope of the Qinling Mountains in Shaanxi province in central China (Figure 1 ). Reproductive data were collected from February to July and survival data obtained from January to December each year. This area is used by ibis for breeding and foraging and the landscape mosaic is characterised by intermontane basins, often developed for rice fields, interspersed with hills. Numerous shallow rivers and streams flow southward through this area into Hanjiang River, a large tributary of the Yangtze River. Forest patches provide $80 \%$ of the coverage used by ibis for nesting. These patches are

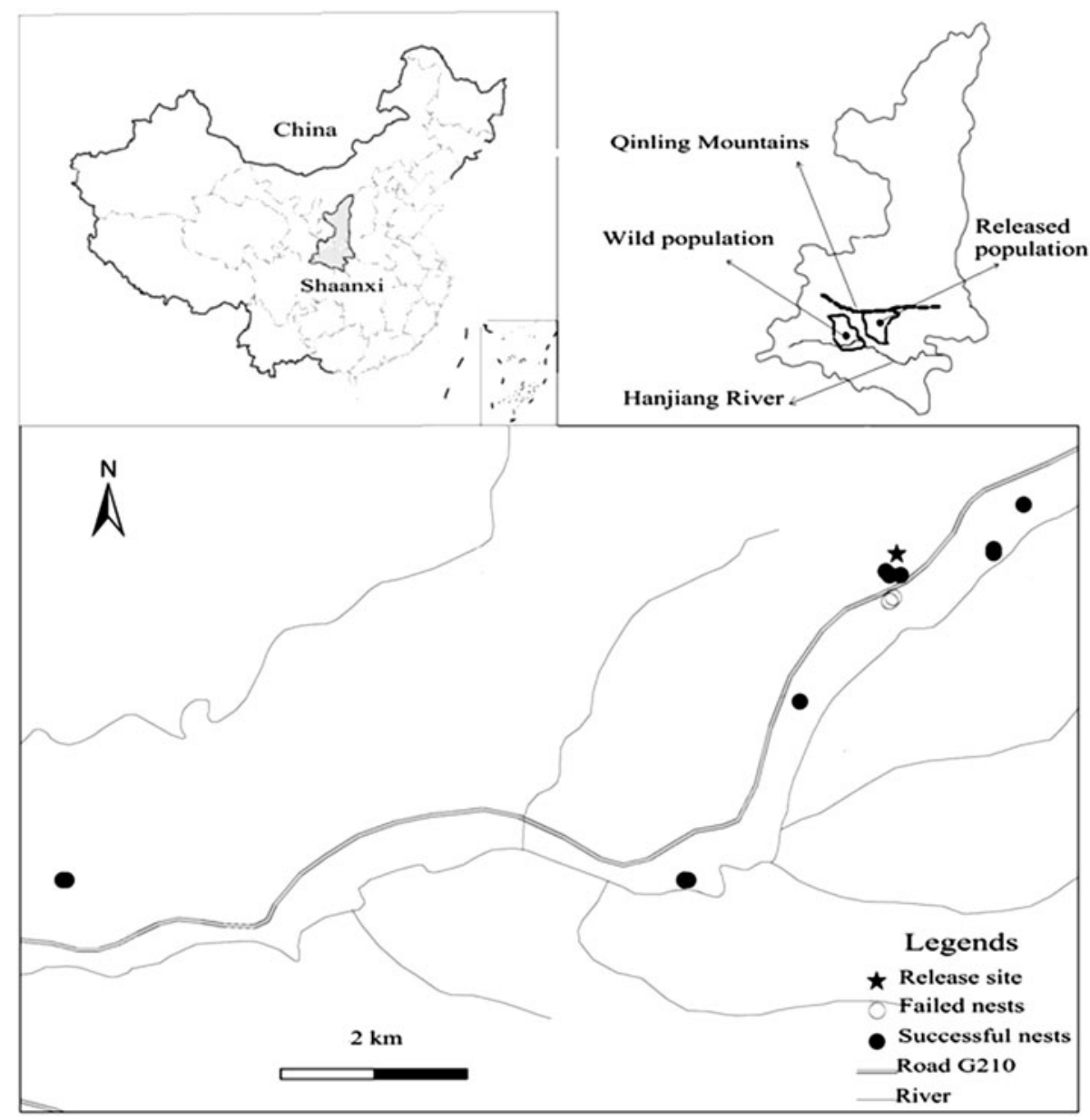

Figure 1. Map of release region showing the location of release site (pentagram), failed (hollow circle) and successful nests (solid circle) for reintroduced population. 
primarily mixed coniferous-broadleaf forest where the dominant tree species include Cork Oak Quercus variabilis, Chinese Pine Pinus tabulaeformis, Chinese Red Pine P. massoniana, and Oriental Arborvitae Platycladus orientalis. Almost all nest sites are found in pine and Cork Oak forest characterised by trees with diameter at breast height (DBH) ranging from five to $40 \mathrm{~cm}$, and canopy heights from 1o to $25 \mathrm{~m}$, planted on a slope near local farm settlements. Breeding pairs will reuse the same nesting territory year after year if not disturbed. Breeding territories are typically small, with a diameter of 50-10om, so distances between nests range from dozens of meters to several kilometres (Shi and Cao 2001).

The study area is in a warm, temperate zone and is relatively humid. The annual temperature averages $12.5^{\circ} \mathrm{C}$ with a frost-free period of 215 days. The mean temperature in January is $0.6^{\circ} \mathrm{C}$ (with a minimum of $-12.8^{\circ} \mathrm{C}$ ) and $23.4^{\circ} \mathrm{C}$ in July (with a maximum of $36^{\circ} \mathrm{C}$ ). Temperatures are warm enough to leave open water in most winters after the release except in January 2007. The annual precipitation is $899 \mathrm{~mm}$ with July to September being the wettest time of the year (latest 10-year period data from Ningshan County meteorological station).

\section{Release and monitoring}

Captive breeding provided an adequate number of individuals for release (Figure 1). Of the 56 individuals released, 20 were transported from the Shaanxi Louguantai conservation centre for endangered species (Zhouzhi County), 20 from the Shaanxi Crested Ibis conservation centre (Yangxian County), and 16 from the Crested Ibis captive breeding centre (Ningshan County). All individuals were held together for 6-12 months before release in a large aviary (a circular nylon cage $20 \mathrm{~m}$ high and $50 \mathrm{~m}$ in diameter) containing roost trees and man-made foraging habitat, allowing training in foraging and flying.

Prior to release, each bird was led into a relatively small aviary by a daily feeding crew and acclimatised for 24 hours in a wooded hacking aviary (measured $60 \times 40 \times 40 \mathrm{~cm}$ ). Birds were provided with fresh food and water while in the hacking aviary. In addition to their normal captive diet, they were treated with a vermifuge such as albendazole and multivitamins. All individuals were uniquely marked with numbered colour bands for field identification. Of the 30 males, 11 were fitted with lightweight radio transmitters weighing $15 \mathrm{~g}$, approximately $1 \%$ of the body weight (model RI-2D; frequency $216.368-216.691 \mathrm{MHz}$; battery life $\sim 18$ months; Holohil Systems, Carp, Ontario, Canada). The radio transmitters were attached to the neck using a harness of elasticated nylon string, leaving room for growth of the pectoral muscles.

Up to the present study, a total of 56 captive-bred ibises have been released: from May to October in 2007 ( 13 females, 13 males); 2008 (four females, two males); 2009 (six females, eight males), and 2011 (three females, seven males), respectively. Among the 14 individuals released in 2009, six birds accidentally escaped from an aviary destroyed by heavy snow on 15 November 2009. All captive-reared birds were banded when they were born in captivity. The mean age of individuals at release was $5.2 \pm 2.5$ years $(n=26)$ for females, and $6.4 \pm 2.9$ years $(n=30)$ for males. Twenty of them paired and 12 females laid eggs in captivity. In the winter following release, birds were provided with supplementary food (mainly loach Misgurnus anguillicaudatus) at the foraging sites they frequently visited. All the observed breeding pairs were monitored during four breeding seasons of 2008 to 2011 from January through to July.

\section{Nest success}

Nests were located by observing behavioural cues of the pair. Crested Ibis fed and roosted extensively near human settlements ( $\mathrm{Li}$ et al. 2002) and all released birds dispersed $\leq 15 \mathrm{~km}$ making it possible to find all nests. The frequent hoarse calls, especially by the male, in early stages of breeding were used to locate breeding birds. Easily accessed nests $(\leq 3 \mathrm{~km}$ from the release site) were monitored every two days, and more remote nests ( $\geq 10 \mathrm{~km}$ from the release site) were monitored 
every four days. We observed to nests for a total of $480 \mathrm{~h}$ during building, 6 nests for $672 \mathrm{~h}$ during incubation and 6 nests for $960 \mathrm{~h}$ during brooding.

The following data were recorded for a total of 21 clutches: ( 1 ) identity (age, sex and bands) of all individuals observed as well as breeders; (2) location of the nest (including the town or village where the nest was located, and the longitude, latitude and altitude of the nest-site); (3) date of egg laying; (4) clutch size; (5) egg losses from each nest; (6) number hatching from each clutch; (7) nestling losses in each clutch; (8) number of chicks fledging from each brood; and (9) species, height and DBH of the nest-tree.

Because the males and females in this species are monomorphic, the sex of each of the pair was determined by observations of copulation behavior during the courtship period. Nest contents were determined using a telescope (Nikon 40x) where possible or through adult and nestling behaviour for inaccessible nests. Transition dates (e.g. egg laying, start of incubation, hatching, and fledging) were observed directly or calculated from the beginning of a known stage in the nesting cycle.

\section{Survival}

We used the staggered entry design of the Kaplan-Meier method (Pollock et al. 1989) to obtain estimates of adult survival (SA) and the first year survival (SJ). We selected this method because newly collared Crested Ibis were introduced into our study area during four separate releases, and it allowed us to take into account emigration or radio loss. The growth rate of the reintroduced population can be calculated approximately as $\lambda=\mathrm{SA}+\left(\mathrm{SJ}{ }^{*} \mathrm{~F} / 2\right)$, where the $\mathrm{F}$ is the average number of young produced/year/pair.

We monitored radio-tagged and band-marked adults 10-15 days/month after release, and as well as the first year fledglings. Nestlings were banded with a unique combination of bands at 24-26 days old when their tarsi were fully developed but before they were able to leave the nest. Simultaneously, a radio transmitter set (RI-2D) was placed on the strongest nestlings (typically the eldest) at each nest. In case of adult or nestling death, carcasses were necropsied to determine cause of death.

\section{Statistical analysis}

Calculation of survival standard errors followed the method of Cox and Oakes (in Pollock et al. 1989). We used the log-rank test to determine annual differences in survival distribution. We used the $Z$-test statistic to examine differences in annual survival rates. We report means \pm SD unless otherwise noted and statistical tests were considered significant at $P<0.05$.

\section{Results}

\section{Breeding behaviour}

Of all released birds, $35.7 \%$ (20 birds) paired and $21.4 \%$ ( 12 females) laid eggs in captivity. All individuals monitored throughout the breeding season following their release paired and had active nests ( $n=$ nine females and eight males; Table 1 ). Of the paired birds, nine of them including five females and four males bred in their first season post-release and two males paired in the third year after release (Table 1 ). We observed to breeding pairs including six captive-captive pairs, two captive-bred males paired with two wild females that immigrated from the wild population in Yangxian County, and one captive-bred male and female paired with sexually mature birds fledged in 2008, respectively. Two males once paired in captivity chose other females for mates and one male remained with its former mate after release. One female and one male ibis reformed the pair bond in the next breeding season when they lost their previous mate (Table I). 


\begin{tabular}{|c|c|c|c|c|c|c|c|}
\hline Breeding pair & Gender & Age & Bands Marked & Release date & Pair formation date & Breeding duration & Remarks \\
\hline I\# & $\begin{array}{l}0 \\
+ \\
0 \\
0\end{array}$ & $\begin{array}{l}5 \\
2\end{array}$ & $\begin{array}{l}375 \\
082\end{array}$ & May 312007 & Dec 2007 & $2008-2010$ & Paired with 279 in captivity. \\
\hline 2\# & $\begin{array}{ll}0 \\
+ \\
1 \\
1\end{array}$ & $\begin{array}{r}10 \\
3\end{array}$ & $\begin{array}{l}\mathrm{R}_{27} \\
359\end{array}$ & May 312007 & Jan 2008 & $2008-$ & Paired with 15 in cantivity \\
\hline $3^{\#}$ & $\begin{array}{l}0 \\
0 \\
+ \\
0 \\
0\end{array}$ & $\begin{array}{l}2 \\
2\end{array}$ & $\begin{array}{l}\mathrm{R}_{2 \mathrm{O}} \\
\mathrm{R}_{21}\end{array}$ & Sep 232008 & Jan 2009 & 2009-2010 & Paired with 159 in captivity. \\
\hline $4 \#$ & $\begin{array}{l}0 \\
+ \\
0 \\
0\end{array}$ & $\begin{array}{l}5 \\
5\end{array}$ & $\begin{array}{l}309 \\
221\end{array}$ & $\begin{array}{l}\text { Sep } 232008 \\
\text { May } 312007\end{array}$ & Dec 2008 & 2008-2010 & The pair bred in captivity for two years. \\
\hline $5 \#$ & $\begin{array}{l}\text { o } \\
+ \\
0\end{array}$ & $\begin{array}{l}11 \text { months } \\
9\end{array}$ & $\begin{array}{l}\text { Wo8 } \\
\text { o94 }\end{array}$ & May 312007 & Mar 2009 & 2009- & Fledgling of 2008. \\
\hline $6 \#$ & $\begin{array}{l}0 \\
+ \\
0\end{array}$ & $\begin{array}{l}3 \\
2\end{array}$ & $\begin{array}{l}\text { W19 } \\
\text { Wo7 }\end{array}$ & Aug 192009 & Dec 2009 & 2010- & $\begin{array}{l}\text { Paired with } 153 \text { in captivity } \\
\text { Fledgling of } 2008 \text {. }\end{array}$ \\
\hline $7 \#$ & $\begin{array}{l}\text { q } \\
0\end{array}$ & $\begin{array}{l}3 \\
3\end{array}$ & $\begin{array}{l}\text { Wo1 } \\
\text { R3O }\end{array}$ & $\begin{array}{l}\text { Aug } 192009 \\
\text { Nov } 152009\end{array}$ & Feb 2010 & 2010- & Paired with $W_{1} 8$ in captivity. \\
\hline $8 \#$ & $\begin{array}{l}0 \\
+ \\
0\end{array}$ & $\begin{array}{l}5 \\
3\end{array}$ & $\begin{array}{l}375 \\
R_{21}\end{array}$ & $\begin{array}{l}\text { May } 312007 \\
\text { Sep } 232008\end{array}$ & Feb 2011 & $2011-$ & Reformed pair bond when its mate 082 was lost. \\
\hline $9 \#$ & $\begin{array}{l}0 \\
+ \\
0\end{array}$ & $\begin{array}{l}2 \\
6\end{array}$ & $\begin{array}{l}\mathrm{C} 63 \\
221\end{array}$ & May 312007 & Mar 2011 & $2011-$ & $\begin{array}{l}\text { From wild population. } \\
\text { Reformed pair bond when its mate } 309 \text { died. }\end{array}$ \\
\hline 10\# & $\begin{array}{l}\text { o } \\
\text { o } \\
\text { o }\end{array}$ & $\begin{array}{r}2 \\
10\end{array}$ & $\begin{array}{l}E_{47} \\
177\end{array}$ & Nov 152009 & Mar 2011 & $2011-$ & From wild population. \\
\hline
\end{tabular}

Table 1. Summary of breeding pairs recorded post release of the reintroduced population in Ningshan County. 
We found 21 nests of 10 pairs (two in 2008, five in 2009, seven in 2010 and seven in 2011). Among them, 17 were successful (at least one nestling fledged), with nest-fate determined by fledging of young. Nests of released birds were exclusively found in trees (2O on Chinese Red Pine and one on David's Poplar Populus davidiana). The nests of wild birds were built on Chinese Red Pine $(n=175)$, Cork Oak $(n=30)$, Siberian Elm Ulmus pumila $(n=19)$, Chinese Pine $(n=5)$, Chinese White Poplar Populus tomentosa $(n=1)$ and Dye-tree Platycarya strobilacea $(n=1)$ (Yu et al. 2006). The nests were large and untidy dish-shaped structures built of sticks in a fork close to the trunk $(n=20)$ or on a fork of a horizontal branch $(n=1)$ of the nest tree. Captive-bred ibis built their nests with dry sticks of Cork Oak, Chinese Red Pine and David's Poplar. The lining materials consisted of dry grass Poa spp., grass roots, leaves of trees and ferns, feathers and human garbage from nearby villages (e.g. pieces of paper or plastic). All the nests in our study were qualitatively similar in construction and site characteristics to those made by wild Crested Ibis (Table 2).

Nest building lasted $17.5 \pm 2.6$ days $(n=21)$ until the first egg was laid, but collection of nest materials occasionally occurred in the following period, especially in the early nestling stage. Males were the primary nest builders ( 510 of 545 observations of collection of nest materials were by males), and females and males developed brood patches, incubated, and brooded young. Mean daily incubation time spent by males $(450.6 \pm 75.4 \mathrm{~min}, n=8)$ was not significantly higher than that by females $(460.5 \pm 54.5 \mathrm{~min}, n=9)(t=0.313, P=0.759)$. Similarly, the mean daily brooding time was not significantly different between males and females $(380.5 \pm 65.5 \mathrm{~min}, n=8$; $365.8 \pm 56.5 \mathrm{~min}, n=9 ; t=0.497, P=0.626$ ). The number of daily feeding bouts delivered to nestlings by males $(45.6 \pm 22.5, n=8)$ was similar to those by females $(43.4 \pm 20.6, n=9$, $t=0.211, P=0.836)$.

A single clutch of $1-5$ eggs (usually four) by each pair was laid in two-day intervals. The egg-laying period lasted approximately three months (2 March to 8 May), compared with I4 March to 8 April for the wild population (Yu et al. 2006). Clutch size was one in one nest, two in six nests, three in four nests, four in nine nests, and five in one nest. Mean clutch size $3.14 \pm$ $1.06, n=21)$ was not significantly larger than that of the wild population $(2.84 \pm 0.77, n=271$, Yu et al. 2006) $(t=1.669, P=0.100)$. Egg viability, measured as the percentage of eggs that hatched out of the total number of eggs that were laid and incubated to term (excluding abandoned or depredated eggs) was $68.2 \%(n=66$ eggs in 21 clutches). Incubation beginning at the first laying date lasted $28-30$ days $(28.5 \pm 1.5$ days; $n=19)$. Nestlings fledged $38-41$ days after

Table 2. Summary of breeding parameters for wild Crested Ibis in Yangxian County in 1981-2004 studied by Yu et al. (2006) and for captive-bred, released birds in Ningshan County in 2008-2011 (present study).

\begin{tabular}{|c|c|c|c|}
\hline & Wild Crested Ibis & $\begin{array}{l}\text { Captive-bred, reintroduced } \\
\text { Crested Ibis }\end{array}$ & Difference \\
\hline Altitude of nest sites (m) & $\begin{array}{l}806.1 \pm 179.7 \\
\quad(n=271,450-1,200)\end{array}$ & $\begin{array}{l}937 \cdot 2 \pm 144 \cdot 9 \\
\quad(n=21,772-1,107)\end{array}$ & $t=3.260, P=0.001$ \\
\hline Height of nest trees (m) & $22.6 \pm 3.8(n=204)$ & $20.0 \pm 6.1(n=21)$ & $t=2.794, P=0.006$ \\
\hline $\begin{array}{l}\text { Height of nests above the } \\
\text { ground }(\mathrm{m})\end{array}$ & $15 \cdot 0 \pm 4.9^{\mathrm{a}}(n=21)$ & $11.4 \pm 2.6(n=21)$ & $t=2.974, P=0.005$ \\
\hline DBH of nest trees $(\mathrm{cm})$ & $43.0 \pm 21.5(n=204)$ & $32.0 \pm 10.3(n=21)$ & $t=2.314, P=0.022$ \\
\hline Egg-laying date ${ }^{b}$ & $11.2 \pm 5.8(n=51)$ & $19.5 \pm 17.6(n=21)$ & $t=3.018, P=0.004$ \\
\hline Clutch size & $2.84 \pm 0.77(n=271)$ & $3.14 \pm 1.06(n=21)$ & $t=1.669, P=0.100$ \\
\hline Egg viability ${ }^{c}$ & $\begin{array}{l}80.2 \% \text { ( } n=271 \text { clutches } \\
\text { and } 770 \text { eggs) }\end{array}$ & $\begin{array}{l}71.5 \% \text { ( } n=21 \text { clutches } \\
\text { and } 66 \text { eggs) }\end{array}$ & $U=27.47, P=0.000$ \\
\hline Fledglings/active nest & $1.96 \pm 1.06(n=231)$ & $1.57 \pm 1.03(n=21)$ & $t=1.618, P=0.107$ \\
\hline Fledglings/successful nest & $2.24 \pm 0.80(n=201)$ & $2.00 \pm 0.87(n=17)$ & $t=1.180, P=0.239$ \\
\hline
\end{tabular}

${ }^{a}$ Data from Shi and Cao (2001).

${ }^{b}$ Mean number of days after 14 March.

cPercentage of eggs that hatched out of the total number of eggs. 
hatching ( $39.5 \pm 2.0$ days; $n=19$ nests). The Crested Ibis exhibited a similar pattern of behaviour in the released and wild populations (Shi and Cao 2001).

\section{Nesting success}

Of 21 active nests with known fates, $81 \%$ (17 nests) fledged at least one young. Four eggs in two clutches of the same pair (Wo8 vs 094, Table 1) in 2009 and 2010 failed to hatch due to the abnormal behaviour (long-time absence during incubation) of the male (094). Similar to wild birds, we confirmed that two reasons accounted for nestling death. A shortage of food in the breeding season was the primary cause, resulting in starvation of the nestlings. Eight of $I_{4}$ fatalities occurred at the early chick stage (one week after hatching). In asynchronous hatching species, the first chicks have usually been the sole beneficiaries of the parents' feeding efforts for a time and certainly receive much more food before younger hatchlings arrive; hence the younger chicks (especially the youngest one) are usually smaller and weaker, and they often die. The corpses of the nestlings were always found under the nest, thrown out by parent birds. Secondly, predators such as snakes (especially King Rat Snake Elaphe carinata) were observed to prey on Crested Ibis nestlings. Four of 14 chicks were lost in this way since 2008. In addition, one nestling died in the broken eggshell during hatching for unknown reasons.

In total, 33 nestlings successfully fledged during the four breeding seasons. There are significant differences in the altitude of nest site, height of nest tree and nest above the ground, and egg-laying date between the released and wild population (Table 2). However, the mean number of fledglings per active nest was $1.57 \pm 1.03(n=21)$, and mean number of fledglings per successful nest was $2.00 \pm 0.87$ (range: $1-4 ; n=17$ ). In comparison, wild birds did not fledge a significantly different number of birds per active nest $(1.96 \pm 1.06, n=231)$ and per successful nest (2.24 $\pm 0.80, n=201$ ) (Yu et al. 2006; Table 2).

\section{Survival}

Overall, 32 of 56 released birds survived their first winter in the area of reintroduction. Since the release, we have extensively monitored the reintroduced population and paid particular attention to the birds' ability to survive during the following winter. We omitted 24 individuals due to signal loss because of transmitter failure or bird emigration from the study area. Mean annual survival rate was $0.572 \pm 0.064(n=56)$ for all released birds, and $0.815 \pm 0.054(n=17)$ for breeders (Figure 2). Although 11 out of 15 (73.3\%) fledglings monitored from 2008 to 2010 survived at least the first winter in their post-fledging dispersal (Yu et al. unpubl. data), the overall survival rate was quite low $(0.515 \pm 0.058, n=33)$. No comparable data are available for wild Crested Ibis. The survival rate for each cohort may be underestimated because some of the released birds and fledglings emigrated outside our study area. Annual survival distributions and survival rates differed significantly among seasons for all released birds $\left(\chi^{2}=4.56, \mathrm{df}=3, P=0.004 ; Z=1.06\right.$, $P<0.01)$, breeders $\left(\chi^{2}=3.12, \mathrm{df}=3, P=0.006 ; Z=3.14, P<0.05\right)$ and first year fledglings $\left(\chi^{2}=2.56\right.$, $\mathrm{df}=3, P=0.001 ; Z=4.06, P<0.001)$, respectively. The average number of young produced/year/ pair was $1.57 \pm 1.03(n=21)$. Then the growth rate $(\lambda)$ of the reintroduced population was 1.2193, compared with that of the wild population $\left(\lambda_{1}=1.0783,1981-1993, \lambda_{2}=1.2014,1994-1997\right.$, and $\lambda_{3}=1.3571$, 1998-2003) (Lu et al. 2000, Ding 2004).

The main results of the field observations to date can be summarised as follows: three females and four males could not be relocated following the release for unknown reasons. Based on evidence found at recovery sites, II mortalities (four females, six males and one of indeterminate sex, its identity ring having been lost) were recorded as five from starvation, one due to electrocution by power lines, two due to predation or injuries attributable to predation (likely by Yellow-throated Marten Martes flavigula, a member of the Mustelidae, and three from unknown causes. 


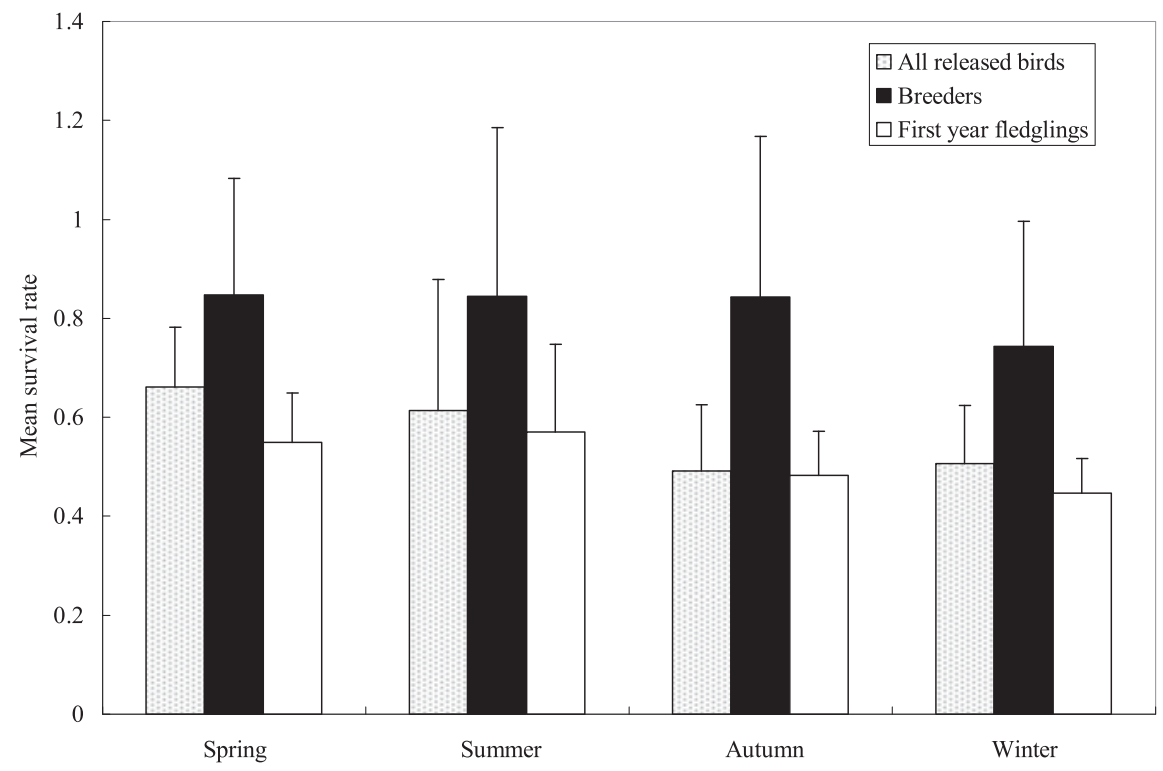

Figure 2. Mean survival rate (average $\pm \mathrm{SE})$ for all released birds $(n=56)$, breeders $(n=17)$ and first year fledglings ( $n=33$ ). Spring ( 1 March to 31 May), summer ( 1 June to 31 August), autumn (1 September to 30 November), winter (1 December to 28 February).

\section{Discussion}

Most reintroduction projects aimed at saving endangered animals in the 1970s and 1980 failed to establish viable populations, partly due to poor planning and subsequent monitoring (Griffith et al. 1989, Wolf et al. 1996). The success of reintroduction programmes depended on the quality of the habitat in which the reintroductions took place, the adaptive ability of the birds to new conditions, as well as the number and age structure of the released birds (Griffith et al. 1989, Wolf. et al. 1996, Armstrong et al. 2002, Tweed et al. 2006). Generally, it seems to be more difficult to reintroduce migratory species successfully than resident ones. For example, in a restoration programme, biologists had to teach Canada Geese Branta canadensis and Trumpeter Swans Cygnus buccinator a safe migration route using ultralight aircraft (Sladen et al. 2002). In the migratory Northern Bald Ibis Geronticus eremita, there has been no successful reintroduction of fully independent individuals into the wild (Boehm et al. 2007). There are a number of reasons responsible for this, including complexities due to migratory behaviour (Akçakaya 1990, Lindsell et al. 2009). The conservation of endangered migratory ibis poses greater challenges than do resident Crested Ibis (Serra et al. 2011). The present study provides evidence for the first successful release of captive-reared Crested Ibis, presenting a meaningful model for reintroduction programmes of other endangered species. In the present reintroduction programme, although the survival rate of reintroduced birds was not as high as that of some species such as Puaiohi Myadestes palmeri released to the wild (Tweed et al. 2006), two pairs fledged young in their first breeding season after release (Yu et al. 2009) and new pair formations continued to occur and the number of fledglings produced continued to increase in the following years.

The reintroduced site is approximately $80 \mathrm{~km}$ from Yangxian County where the wild population survived (Figure 1 ). We have never found any wild individuals in this area during the pre-investigation of feasibility for release. Based on the definition of reintroduction by IUCN (1998), strictly speaking, this is a purely reintroduced population. However, it could also be classed as a restocking programme as two females from the wild population mated with released birds through natal dispersal. 
There were no obvious differences in reproductive behaviour and general breeding patterns between the released (present study) and wild population (Shi and Cao 2001), but there are a few differences in egg-laying date and clutch size. The relative extended duration of egg-laying (from 2 March to 8 May) for the released population may be the result of local ecological conditions such as food availability (Armstrong et al. 2002). The clutch size of the reintroduced population (3.14 $\pm 1.06, n=21$ ) was slightly higher than that of wild population $(2.84 \pm 0.77, n=271)$. This may reflect a different age structure of the two populations. For the wild population, the clutch sizes achieved by $2-3$ year-old and $\geq 10$ year-old individuals were significantly lower than that of 4-1o year-old birds (Yu et al. 2007).

Predation was one of the main causes of nest loss in both the reintroduced and wild populations (Shi and Cao 2001, Yu et al. 2006, present study). The important predators include King Rat Snake, which usually attacks eggs and chicks, and Yellow-throated Marten and Siberian Weasel Mustela sibirica, which may also prey on adults as well as their eggs and nestlings (Cao et al. 1995, Xi et al. 1997, Zhang et al. 2000). A total of 40 eggs and 15 chicks were taken by nest predators from 1981 to 2004 (Yu et al. 2006). Four nestlings died from predation by King Rat Snake in our 4-year study period. These predation events occurred occasionally during the nestling stage, when nests are more conspicuous because of nestling begging calls, increased visitation by adults, and the scent of feces under nest tree. Corvids, such as Collared Crow Corvus torquatus, Black-billed Magpie Pica pica and Red-billed Blue Magpie Urocissa erythrorhyncha often nest on the same tree or in forest patches very close to the breeding territory of the Crested Ibis, and may be a threat. Observations on the wild birds showed that crows have preyed on two eggs of a clutch in only one case in 1981 (Shi and Cao 2001, Yu et al. 2006). However, incubation failure of the released ibis population on Sado Island in Japan in 2010 was completely due to egg predation by crows Corvus spp. (Nishimiya and Hayashi 2010). We interpret that egg loss from predation to imply there is a high density population of crows on Sado Island.

We conclude that snake predation is one of the serious problems affecting recovery of the Crested Ibis in release areas. A predation event usually occurs quickly and often under circumstances that make observation difficult. Since 2008, one King Rat Snake was captured and three were driven away from the nest. A series of approaches to protecting Crested Ibis and their young from snake predation using plastic cloth covering the trunks of nesting and adjacent trees, and bait (poisoned chicken eggs) has not been very effective. A total of 40 eggs and 15 chicks in the wild population were taken by nest predators from 1981 to 2004 (Yu et al. 2006), and four nestling mortalities were due to snake predation in the released population (present study). Hence, there is an urgent need for a cost-effective management technique that can be applied at an ecosystem level.

The most promising result from our monitoring efforts was that captive-bred ibis successfully paired and fledged young in the wild within the first breeding season (Yu et al. 2009). The two fledglings produced in the 2008 breeding season (part of the first generation) paired with released individuals in 2009 and 2010 and fledged six young (the second generation) in the following breeding season. In total, $81 \%$ ( 17 out of 21 ) of nests fledged at least one young, and most of the fledglings survived to complete their post-fledging dispersal (Yu et al. unpubl. data). Furthermore, two captive-bred birds paired with two wild individuals that had dispersed long distances from the wild population in Yang Xian County.

Our results strongly lead us to recommend that: (I) The Crested Ibis was once a summer resident in the north of its former range, such as Siberia, north-eastern China and Hokkaido of Japan (Shi and Cao 2001). Hence, further releases should be given priority in regions on the southern slope of the Qinling Mountains where the Crested Ibis was resident. Thus, the forthcoming Crested Ibis release programme in Henan Province of central China must focus on how to guide the released birds to complete their migration (Yu unpubl. data). (2) At the meta-population level (Armstrong and Seddon 2007), multiple releases should be conducted among different sites away from the core (wild) population in Yangxian County. Each reintroduced population would be expected to become a satellite population once the wild individuals dispersed to the reintroduced 
areas to mate with released individuals. (3) Birds that have previously bred in captivity, and their offspring, should be a high priority for release into the wild. (4) Although continued releases at one site are not always necessary (Armstrong and Ewen 2001), the study population would have benefited from additional releases, because new pair formations continued to occur after subsequent releases. (5) In the wild population, the mean weight of supplementary food per nest was significantly correlated with the overall breeding success of each year (Yu et al. 2006). Food supplementation, especially in the breeding season, is therefore essential to guarantee the survival of more releases. (6) Public education should be implemented to inform local people of the purpose of ibis conservation and on how to get involved.

\section{Acknowledgements}

We are very grateful to the reintroduction base of Crested Ibis in Ningshan County for logistical help and research aid. We thank Cao Hai-xin, Shi Liang, Guo Jun-feng and Ma Xiao-chun for obtaining the breeding data, Ren Wei for editing the manuscript, Wang Yu-zhou for drawing the maps, and Ningshan County meteorological station for providing meteorological information. This work was completely supported by National Nature Science Foundation of China under grant number 31172103 .

\section{References}

Akçakaya, H. (1990) Bald Ibis Geronticus eremita population in Turkey: An evaluation of the captive breeding project for reintroduction. Biol. Conserv. 51: 225-237.

Archibald, G. W., Lantis, S. D. H. and Munetchika, I. (1980) Endangered ibises, Threskiornithinae: Their future in the wild and in captivity. Int. Zoo. Yearbook 20: 6-17.

Armstrong, D. P. and Ewen, J. G. (2001) Assessing the value of follow-up translocations: A case study using New Zealand robins. Biol. Conserv. 101: 239-247.

Armstrong, D. P. and McLean, I. G. (1996) New Zealand translocations: Theory and practice. Pacific Conserv. Biol. 2: 39-54.

Armstrong, D. P. and Seddon, P. J. (2007) Directions in reintroduction biology. Trends Ecol. Evol. 23: 20-25.

Armstrong, D. P., Castro, I., Alley, J. C., Feenstra, B. and Perrott, J. K. (1999) Mortality and behavior of Hihi, an endangered New Zealand honeyeater, in the establishment phase following translocation. Biol. Conserv. 89: 329-339.

Armstrong, D. P., Davidson, R. S., Dimond, W. J., Perrott, J. K., Castro, I., Ewen, J. G., Griffiths, R. and Taylor, J. (2002) Population dynamics of reintroduced forest birds on New Zealand islands. J. Biogeogr. 29: 609-621.

Black, J. M. and Banko, P. C. (1994) Is the Hawaiian goose (Branta sandvicensis) saved from extinction? Pp. 394-410 in P. J. S. Olney, G. M. Mace, and A. T. C. Feistner, eds. Creative conservation: Interactive management of wild and captive animals. New York: Chapman \& Hall.

Boehm, C., Bowden, C. G. R., Jordan, M. and King, C., eds. (2007) Northern Bald Ibis conservation and reintroduction workshop, Vejer, Spain. Sandy, UK: RSPB.

Cade, T. J. and Jones, C. G. (1993) Progress in restoration of the Mauritius kestrel. Conserv. Biol. 7: 169-175.

Cade, T. J. and Burnham, W. (2003) Return of the Peregrine. Boise, Idaho: The Peregrine Fund.

Cao, Y. H., Yu, X. P. and Zhai, T. Q. (1995) The harm made by snakes to the Crested Ibis, Nipponia nippon, in breeding season. J. Northwest Univ. 25(SL): 721-724. (In Chinese).

Collar, N. J., Crosby, M. J. and Stattersfield, A. J. (1994) Birds to watch 2. The world list of threatened birds. Cambridge, UK: BirdLife International.

Ding, C. Q. (2004) Research on the Crested Ibis. Shanghai: Shanghai Scientific \& Technical Publishing House. (In Chinese).

Green, R. E. (1997) The influence of numbers released on the outcome of attempts to introduce exotic bird species to New Zealand. J. Anim. Ecol. 66: 25-35. 
Griffith, B., Scott, J. M., Carpenter, J. W. and Reed, C. (1989) Translocation as a species conservation tool: status and strategy. Science 245: 477-480.

IUCN (1998) Guidelines for reintroductions. Gland, Switzerland, and Cambridge, UK: IUCN/SSC Re-introduction Specialist Group. Jones, C. G., Heck, W., Lewis, R. E., Mungroo, Y., Slade, G. and Cade, T. (1995) The restoration of the Mauritius Kestrel Falco punctatus population. Ibis 137 (Supplement) : $\mathrm{S}_{173}-\mathrm{S}_{1} 80$.

Li, F. L. (1991) World's first captive breeding of the Japanese Crested Ibis Nipponia nippon. J. Yamashina Inst. Ornithol. 22: 70-76.

Li, X. H., Ma, Z. J., Ding, C. Q., Zhai, T. Q. and Li M. (2002) Relationship between the distribution of Crested Ibis and local farmers. Acta Zool. Sinica 48: 725-732. (In Chinese).

Lindsell, J. A. G., Serra, L., Peške, Ghazy Al Qaim, M. S. A., Kanani, A. and Wondafrash, M. (2009) Satellite tracking reveals the migration route and wintering area of the Middle East population of Critically Endangered northern bald ibis Geronticus eremita. Oryx 43: 329-335.

Liu, Y. Z. (1981) The re-discovery of the Crested Ibis in Qinling Mountain. Acta Zool. Sinica 27: 273 (In Chinese).

Lu, B. Z., Fu, W. K., Zhai, T. Q., Xi, Y. M., Zhang, Y. M. and Huang, L. (200o) Study on population structure and population dynamics of the Crested Ibis. Pp. 97-103 in Proceedings of International Workshop on the Crested Ibis Conservation '99. Beijing: China Forestry Publishing House (In Chinese).

May, R. (1991) The role of ecological theory in planning re-introduction of endangered species. Symp. Zool. Soc. London 62: 145-163.

Mcphee, M. E. and Silverman, E. D. (2004) Increased behavioral variation and the calculation of release numbers for reintroduction programs. Conserv. Biol. 18: 705-715.

Meretsky, V., Snyder, N. F. R., Beissinger, S. R., Clendenen, D. A. and Wiley, J. W. (2001) Quantity versus quality in California Condor reintroduction: reply to Beres and Starfield. Conserv. Biol. 15: 1449-1451.

Nishimiya, H. and Hayashi, K. (2010) Reintroducing the Japanese Crested Ibis in Sado, Japan. TEEBweb.org.
Pollock, K. H., Winterstein, S. R., Bunck, C. M. and Curtis, P. D. (1989) Survival analysis in telemetry studies: the staggered entry design. J. Wildl. Manage. 53: 7-15.

Rudolph, D. C., Conner, R. N., Carrie, D. N. and Schaefer, R. R. (1992) Experimental reintroduction of red-cockaded woodpeckers. Auk 109: 914-916.

Sarrazin, F. and Barbault, R. (1996) Reintroduction: challenges and lessons for basic ecology. TREE 11: 474-478.

Seddon, P. J., Armstrong, D. P. and Maloney, R. F. (2007) Developing the science of reintroduction biology. Conserv. Biol. 21: 303-312.

Serra, G., Bruschini, C., Lindsell, J. A., Peske, L. and Kanani, A. (2011) Breeding range of the last eastern colony of critically endangered Northern Bald Ibis Geronticus eremita in the Syrian steppe: a threatened area. Bird Conserv. Internatn. 21: 284-295.

Shi, D. C. and Cao, Y. H. (2001) The Crested Ibis in China. Beijing: China Forestry Publishing House. (In Chinese).

Simberloff, D. (1988) The contribution of population and community biology to conservation science. Annu. Rev. Ecol. Syst.19: 473-511.

Sladen, W. J. L., Lishman, W. A., Ellis, D. H., Shire, G. G. and Rininger, D. L. (2002) Teaching migration routes to Canada Geese and Trumpeter Swans using ultralight aircraft, 1990-2001. Waterbirds 25(Special publication): 132-137.

Tweed, E. J., Foster, J., T., Woodworth, B. L., Monahan, W. B., Kellerman, J. L. and Lieberman, A. (2006) Breeding biology and success of a reintroduced population of the critically endangered Puaiohi (Myadestes palmeri). Auk 123: 753-763.

Wolf, C. M., Garland, T. J. R. and Griffith, B. (1998) Predictors of avian and mammalian translocation success: Reanalysis with phylogenetically independent contrasts. Biol. Conserv. 86: 243-255.

Wolf, C. M., Griffith, B., Reed, C. and Temple, S. A. (1996) Avian and mammalian translocations: update and reanalysis of 1987 survey data. Conserv. Biol. 10: 1142-1154.

Xi, Y. M., Lu, B. Z., Geng, Z. Z., Zhai, T. Q. and Zhang, Y. M. (1997) Cure of the Crested Ibis. Chinese Wildl. 18: 28-30. (In Chinese). 
Yamashina, Y. (1967) The plight of the Japanese Crested Ibis. Animals 10: 275-277.

Yu, X. P., Chang, X. Y., Li, X., Chen, W. G. and Shi, L. (2009) Return of the Crested Ibis Nipponia nippon: a reintroduction programme in Shaanxi province, China. Birding ASIA, 11: 80-82.

Yu, X. P., Liu, N. F., Xi, Y. M. and Lu, B. Z. (2006) Reproductive success of the crested ibis Nipponia nippon. Bird Conserv. Internatn. 16: 325-343.
Yu, X. P., Lu, B. Z., Lu, X. R. and Liu, N. F. (2007) Influences of age on the reproductive success of the crested ibis Nipponia nippon. Acta Zool. Sinica 53: 812-818. (In Chinese).

Zhang, Y. M., Lu, B. Z., Zhai, T. Q., Xi, Y. M. and Wang, Y. J. (2000) Analysis on the death reason and conservation measures of Crested Ibis. Pp. 117-122 in Proceedings of International Workshop on the Crested Ibis Conservation '99. Beijing: China Forestry Publishing House. (In Chinese).

\section{XIAOPING YU*, ZHIPING HUO}

Co-Innovation Center for Qinba regions' sustainable development, College of Life Sciences, Shaanxi Normal University, 710062, Xi'an China.

\section{XIA LI}

Crested Ibis Reproduction Center, Shaanxi Ningshan Forestry Administrations, Ningshan, 72500o, China.

${ }^{*}$ Author for correspondence; e-mail: yuxp64@163.com

Received 7 May 2013; revision accepted 3 March 2014; Published online 11 December 2014 